\title{
THE UPTAKE OF PENTAZOCINE INTO BRAIN
}

F. Medzihradeky and $\mathrm{K}$. Ahmad*

Departments of Blological Chemistry and Pharancology and the Upjohn Center for Clinical Pharmacology, The Univerafty of Michigan, Ann Arbor, Michigan 48104

(Received 16 February 1971; in final form 27 May 1971)

\section{Sunmary}

A simple procedure for the extraction from tissues and determination by gas chromatography of pentazocine was developed. The mean recovery from brain was $96 \%$.

The time- and dose-dependent uptake of pentazocine into the brain was investigated and correlated with the plasma levels of the drug. The results showed a rapid entry of pentazocine into the brain; peak concentrations in plasma and brain were obtained at $2 \mathrm{~min}$ and $10 \mathrm{~min}$, respectively, after the 1.p. administration. After the injection of a ingle dose, the ratio, concentration of pentazocine in plasma/concentration of pentazocine in brain was constant from 10-90 min. Thls ratio remsined unchanged over the range of $25-100 \mathrm{mg} / \mathrm{kg}$ of administered drug.

After the observation that phenazocine $(1,2,3,4,5,6$-hexahydro-6, 11-dimethy1-3-phenethy1-2,6-methano-3-benzazoc1n-8-01), a benzomorphan (BMO derivative was a strong analgesic (1), a number of other comounds with similar chemical atructures were prepared $(2,3)$ and aubjected to pharnacological and clinical evaluation $(4,5,6,7)$. Pentazocine $(1,2,3,4,5,6$-hexahydro-6, 11 d!methyl-3-(3-methyl-2-buteny1)-2,6-methano-3-benzazoc1n-8-ol), a clinically used BM derivative has been reported to be a potent analgesic in man, ufth low Incidence of adverse effects (8) and minfmum addiction liability $(4,5)$. The distribution of cyclazocine $(1,2,3,4,5,6$-hexahydro-6,11-dinethy1-3-cyclopropy1methyl-2,6-methano-3-benzazocin-8-o1), another BM derivative and pentazocine has been studied in dogs and cats using the tritlated drugs $(9,10)$. In these experiments radioactivity in the brain was higher than in blood or plasma suggesting an easy penetration of the drugs through the blood-brain barrier. 
However, no Identification of the radioactivity was made.

The present investigation was undertaken to study the entry of pentazocine Into the brain of rats and correlate its concentration in this organ with that In plasma. Exiating methods of determination of pentarocine $(11,12)$ do not Include estimation of the drug from tisaues. Therefore, a procedure was developed for the extraction of pentazocine from brain and 1ta quantitation by gas chroma tography.

\section{Experimental Procedure}

Pentazocine and cyclazocine were supplied as bases. Stock solutions were prepared In $0.9 \% \mathrm{NaCl}$ by adjusting the pH to 4 with HCl. Cyclazocine was used as the Internal standard in the gas chromatographic procedure. The chemicals used were of analytical reagent grade.

Male Sprague-Dowley rats weighing $300 \mathrm{~g}$ were used. In the first set of experiments seven groups of four rats each were injected 1.p. (1 ml) with $50 \mathrm{mg} / \mathrm{kg}$ pentazocine in $0.9 \% \mathrm{NaCl}$. The rats in the individual groups were decaptitated at $2,5,10,30,60,90$ and $150 \mathrm{~min}$ after administration of the drug. Ten min prfor to decapitation, heparin, $0.15 \mathrm{ml}$ of $1 \mathrm{mg} / \mathrm{ml}$ solution in 0.97 NaCl was administered, 1.p. to all animals. The rats sacrificed at 2 and $5 \mathrm{~min}$ received heparin 8 and $5 \mathrm{~min}$ prior to the adminlatration of the drug, whereas those decapitated at 10 min recelved pentazocine and heparin simultaneously by separate infections. The blood was collected into centrifuge tubes; the brain (excluding the cerebellum) was immediately removed, quickly rinsed in cold $0.9 \% \mathrm{NaCl}$, blotted dry and stored at $-20^{\circ} \mathrm{C}$. The separated plasma was kept at $-20^{\circ} \mathrm{C}$ unt 11 analyola.

In the second set of experiments, four groups of four rats were infected 1.p. ( $1 \mathrm{ml}$ ) with $25,50,75$ and $100 \mathrm{mg} / \mathrm{kg}$ pentazocine respectively. These animals were decapitated at 60 min after the administration of the drug. The further treatment of the animals as well as the sampling of plasma and brain were as described before. 
Pentazocine In plasma was analyzed according to the gas chromatographic procedure developed for the determination of BM derivatives in human plasm (13)

The brain was homogenized with $0.1 \mathrm{~N} \mathrm{HCl}$ (10 m1/8 tissue) in a PotterElveh jem all-glass homogenizer. The homogenate was centrifuged at $9000 \times \mathrm{g}$ for $10 \mathrm{~min}$ and the oupernatant was collected. The sediment was suspended $1 \mathrm{n} 5 \mathrm{ml}$ of $0.1 \mathrm{~N} \mathrm{HCl,} \mathrm{centrifuged} \mathrm{and} \mathrm{the} \mathrm{supernatent} \mathrm{was} \mathrm{added} \mathrm{to} \mathrm{that} \mathrm{previously}$ collected. Cyclazocine, used as Internal standard, was added (0.2 ml of $100 \mu \mathrm{g} / \mathrm{ml}$ ) to $12 \mathrm{ml}$ of the acidic extract. After adjustment of the $\mathrm{pH}$ to 8 with $0.5 \mathrm{ml}$ of $1 \mathrm{~N} \mathrm{NaOH,} \mathrm{the} \mathrm{drug} \mathrm{was} \mathrm{extracted} \mathrm{with} 20 \mathrm{ml}$ benzene for $10 \mathrm{~min}$ on a horizontal shaker at medium speed. The samples then were centrifuged at $1900 \times 8$ for $20 \mathrm{~min}$. Fifteen $\mathrm{ml}$ of the organic layer was transerred to contcal tubes and evaporated to dryness on a water bath at $65^{\circ} \mathrm{C}$ under atream of nitrogen. Just prior to analysis the residue was dissolved in $50 \mu 1$ acetone and 1-2 $\mu 1$ 1njected into the gas chromatograph.

The amount of pentazocine in a sample was determined by measuring the rat10, peak height of the drug/peak height of Internal standard, and relating this ratio to previously constructed standard curves obtained by using rat plasma and rat brain, respectively. These standard curves were linear over : wide range (25 to $500 \mathrm{ng}$ ). A dual column gas chromatograph (Hewlett-Packard, Model 402) equipped with flame Lonization detectors was used. Glass columns 6 feet long, $1 / 4$ 1nch O.D. were packed with $3 \%$ ov-1 gas chrom $Q(100 / 120$ mesh). The columins were conditioned for 48 hours at $260^{\circ} \mathrm{C}$. Operating conditfons were: colum temperature $210^{\circ} \mathrm{C}$, infection port $250^{\circ} \mathrm{C}$ and flame detector $260^{\circ} \mathrm{C}$. Nitrogen flow was $35 \mathrm{ml} / \mathrm{min}$; hydrogen and als was adjusted to give optfmum detector response.

\section{Results}

Typical chrometograms of pentazocine extracted from plasma and braln after the 1.p. administration to rats are shown in Fig. 1. The retention time for the Internal standard (cyclazocine) was $5.0 \mathrm{~min}$ and for pentazocine $5.7 \mathrm{~min}$. 
No Interference by the blological meterial was encountered.

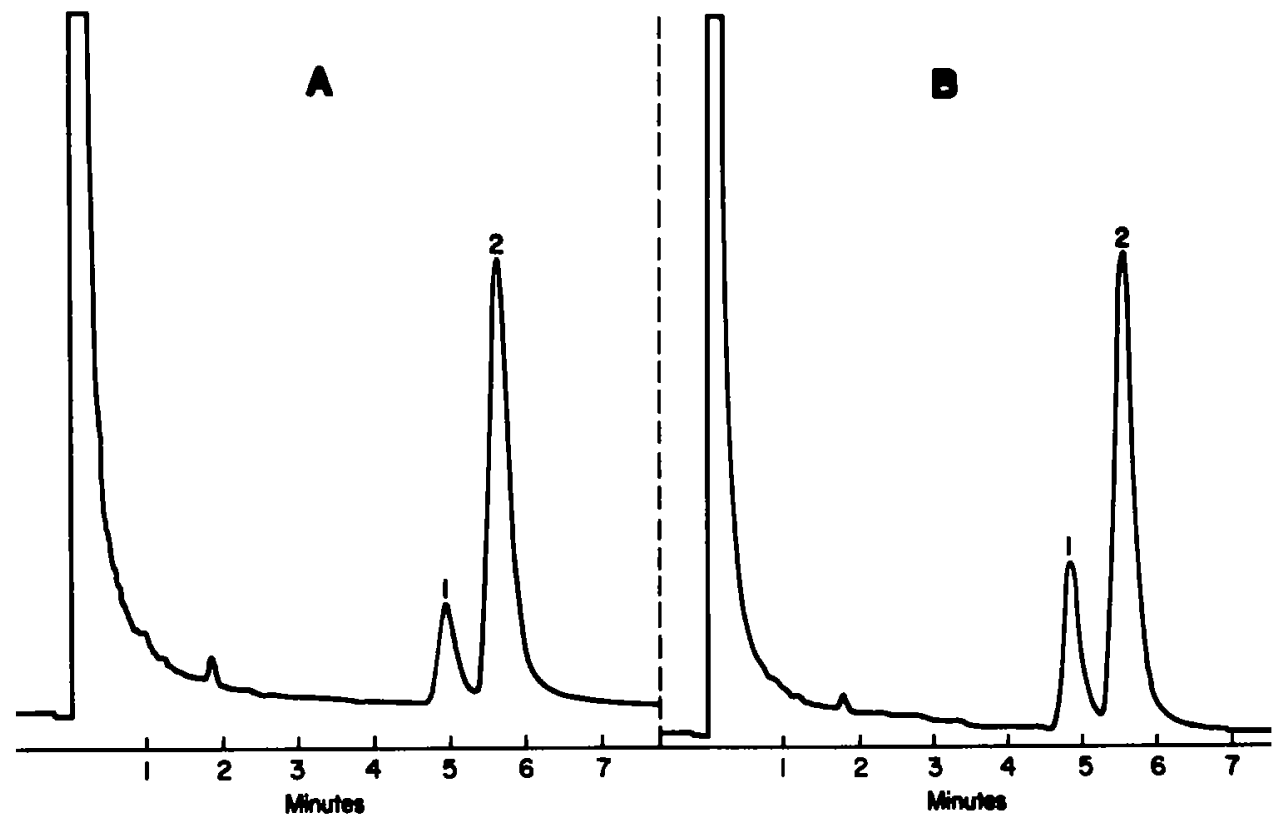

FIG. 1

Gas chromatographic aeparation of A: $60 \mathrm{ng}$ of cyclazocine and $240 \mathrm{ng}$ of pentazocine from rat plasma and B: $100 \mathrm{ng}$ of cyclazoctne and $300 \mathrm{ng}$ pentazocine from rat brain homogenate, after the 1.p. administration of pentazocine.

Table 1 shows the recovery of pentazocine from plasma and brain of rats.

In these experiments known amounts of pentazocine $(2$ to $16 \mu \mathrm{g} / \mathrm{ml}$ plasme or 4.98 to $38.46 \mu \mathrm{g} / \mathrm{g}$ brain tissue) were added to plasma or braln homogenate of untreated rats and the drug extracted as described. The mean recovery of pentazocine from plasm and brain was 100 and $96 \%$, respectively. 


\section{TABLE I}

Recovery of pentazocine from rat plasma and rat brain homgenate. The resulte represent the mean \pm S.D. of 4 rats. The figures in parenthesis exprese $z$ recovery of the drug.

\begin{tabular}{|c|c|c|c|}
\hline \multicolumn{2}{|c|}{ Amount of drug edded } & \multicolumn{2}{|c|}{ Anount recovered } \\
\hline to placem & $\begin{array}{l}\text { to brain } \\
\text { bowogenate }\end{array}$ & from plesme & $\begin{array}{l}\text { from brain } \\
\text { homogenate }\end{array}$ \\
\hline 2 & 4.98 & $1.96 \pm 0.12$ & $4.68 \pm 0.42(94)$ \\
\hline 4 & 9.90 & $4.12 \pm 0.31(103)$ & $9.75 \pm 1.01(98)$ \\
\hline 8 & 19.61 & $7.96 \pm 0.26$ & $18.14 \pm 1.96$ \\
\hline \multirow[t]{2}{*}{16} & 38.46 & $16.36 \pm 0.41(102)$ & $38.20 \pm 2.21$ (99) \\
\hline & & Mean: & $96 \%$ \\
\hline
\end{tabular}

The concentration of pentazocine in plesme and brain of rats after an 1.p. dose of $50 \mathrm{mg} / \mathrm{kg}$ ts ahown In F1g. 2. The plasma concentration dropped rapidly from $10.18 \mu \mathrm{g} / \mathrm{ml}$ at $2 \mathrm{eln}$ to $2.92 \mu \mathrm{g} / \mathrm{ml}$ at $10 \mathrm{~min}$ after the adminiatration. During this time the concentration of the drug in the brain rose frow $3.50 \mu \mathrm{g} / \mathrm{g}$ to $11.92 \mu \mathrm{g} / \mathrm{g}$. At all times the concentration of the drug in brain was higher than in plesan. The mean ratio, concentration in plasma/ concentration in brain $(P / B)$ of 0.24 reached at $10 \mathrm{~min}$, was meinteined until $90 \mathrm{~min}$. The ratio rose to 0.48 at 150 min after the administration of pentazocine. 


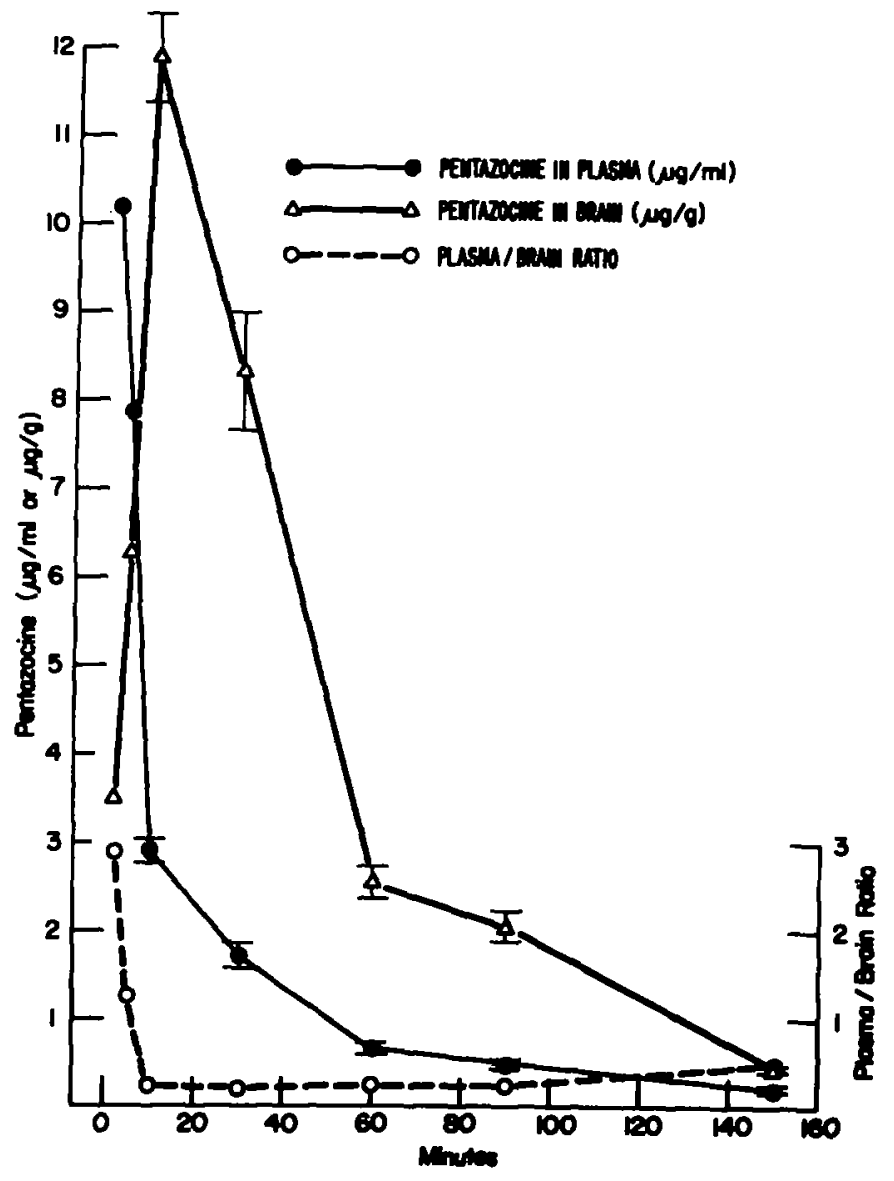

FIG. 2

Concentration of pentazocine in plasma ( $\longrightarrow$ ) and brain $(\Delta-\Delta)$ of rats at verious times after the $1 . p$. administration of $50 \mathrm{mg} / \mathrm{kg}$ of the drug. Each point $1 \mathrm{~g}$ the mean \pm S.D. of 4 rats. The S.D. at 2 and 5 min has been onitted for clarity. The broken line $(0--0)$ shows the ratio, concentration of drug in plasma/concentration of drug in brain.

F1g. 3 showe the concentration of pentazocine in plasa and brain of rats at $60 \mathrm{~min}$ after the 1.p. administration of $25,50,75$ and $100 \mathrm{mg} / \mathrm{kg}$. With increase of dose, the drug concentration in plases and brain rose proportion- 
ately resulting in a constant mean $P / B$ ratio of 0.28 .

In control experdmats, rate recelved $0.15 \mathrm{ml}$ of $0.97 \mathrm{kaCl}$, lastead of heparin, and absequently the concentration of pentazocine in brain was deternined. The results agreed well with those obtalned after the administration of the corresponding doses of pentasocine to heparinized rats.

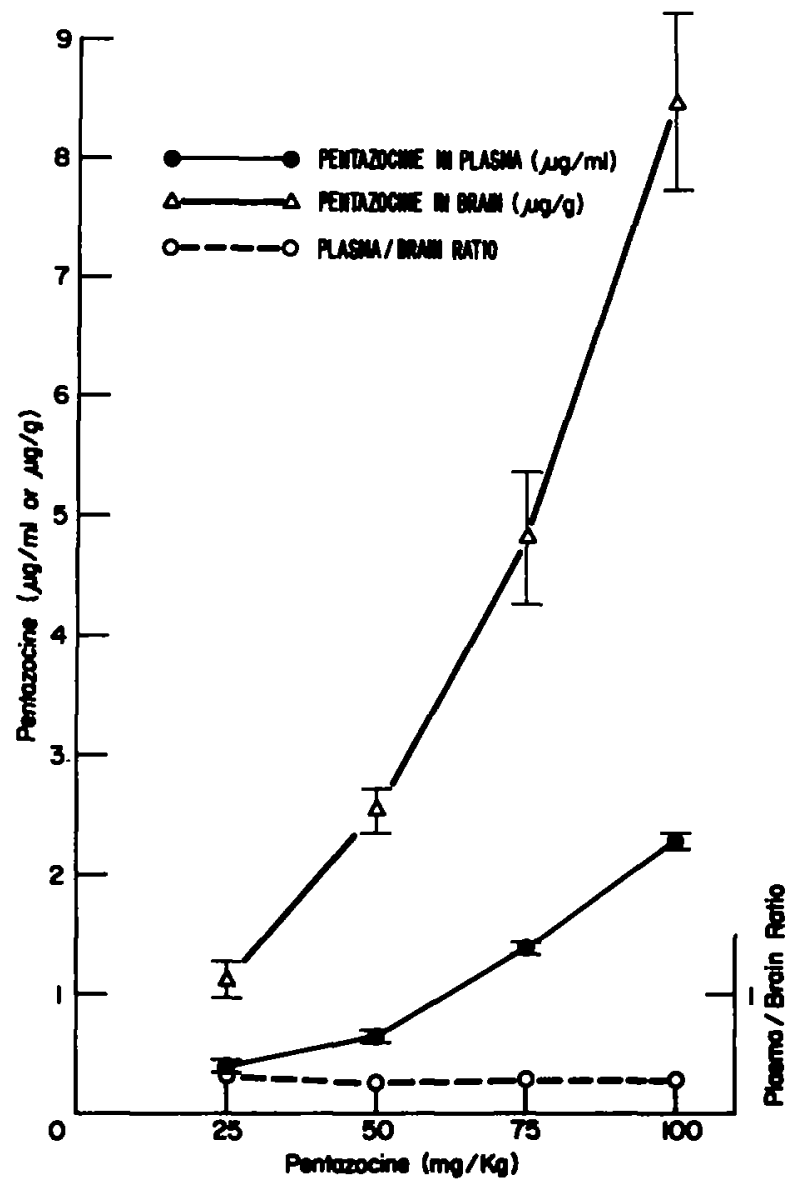

FIG. 3

Concentration of pentazocine in plesing ( $(-\Delta)$ and brain $(\Delta-\Delta)$ of rats at $60 \mathrm{mln}$ after the 1.p. adulnietration of increasing dones of the drug. Each point is the man \pm s.D. of 4 rats. The broken line $(0--0)$ show the ret1o, concentration of drug in placia/concentration of drug in brain. 


\section{Discusaton}

The previously reported tissue levels of pentazocine were obtained by the use of the radioactively labeled drug $(10,14)$. The simple procedure for the determination of pentazocine in brain described in this comminication allows the quantitation of the drug by gas chromatography. Good chromatographic separation of the internal standard and of pentazocine was achieved, and no Interfering peaks were obtained from the biological weterial (Fig. 1). The high recovery of the drug from bratn homogenates (Table 1) suggest the appl1cablity of the procedure to other tissues as well. In combination with the described gas chromatographic determination of other benzomorphlne derivatives (13) the procedure presented here could be used for the analysis of these compounds in tissues.

The analysis of plasma and brain after the addition of known amounts of pentazocine, as well as after the $1 . p$. administration of the drug to rats, ylelded Identical chromatograms both showing single well resolved peaks with a retention time of 5.7 minutes. No interference by peaks having similar retention times was encountered. Pentazocine is mainly metabolized by oxidation of the terminal methyl groups of the dimethylaliyl side-chain to yleld two 1someric alcohols. The relative retention times of these metabolites as compared to pentazocine $(1.00)$ were determined to be 2.06 and 2.30 respectively (14).

In agreenent with the rapid onset of action observed clinically (11) the concentration of pentazocine in brain reached a high level quickly: peak levels were obtained $10 \mathrm{~min}$ after the $1 . p$. administration of the drug (F1g. 2). Pentazocine also leaves the brain rapldiy: at $60 \mathrm{~min}$ after the adminfotration, the level in brain represented less than $25 \%$ of the peak concentration. After $60 \mathrm{~min}$ the decline was considerably slower. The peak of plasma levels obtained at $2 \mathrm{~min}$ after administration rapidly declined at 60 min to $10 \%$ of 1 ts original value. of particular interest was the finding 
that during these raptd and large changes in concentration of the drug, the P/B ratio remined essentially constant from $10 \mathrm{~min}$ to 90 ain after the adainistration. The constency of the blood/tissue ratio was even wore accentuated in the experinents when Increasing doses of pentarocine vere Injected 1.P.: over the range of $25-100 \mathrm{mg} / \mathrm{kg}$, the $P / B$ ratio remained unchanged. Therefore, plasm levels are apparently indicative of the concentration of pentazocine in the brain.

The results presented in this comsunication show that peatazocine with a mlecular weight of 285 obviously penetrates blological membranes quite aesily and the blood/brain berrier seens to have little reetricting effect on the entry of this compound into the braln. Pentazocine at a bastc amine 1s Iikely to concentrate in tiseues, and its high partition coefficient between organic and aqueous phase (10) expasizes its 11pophilic nature. However, the present study demonetrates a pronounced and rapid exchenge of the drug between compartments separated by blological nembranes and justifies further work to elucidate the wechanien of this transport. Such work is in progress.

\section{Acknowled grents}

The euthors wiah to thenk Dr. J.B. Villerreel, Depertment of Phernacology, University of Mlchigan, for helpful discussione and for the generous supply of pentazocine and cyclasocine. Th1s work was supported in part by PHS Grants 5 P11 GY 15559 and 5 TO1 HEO5526.

\section{Referencee}

1. B.L. MaY and N.B. RDDY, J. Org, Chew. 24, 1435 (1959).

2. Mo CORDON, J.J. LAFTLATY, D.H. TEDESCHI, M.B. EDDY and E.L. MY, Pature 192, 1088 (1962).

3. S. ARChls, M.F. ALBERTBOA, L.8. GARRIS, A.K. PIERSOA and J.G. BIRD J. Chen. I, 123 (1964). 
4. H.F. FRASER and D.E. ROSENBERG, J. Phermacol. Exp. Therep. 143, 149 (1964).

5. A.S. EEATS and J. TELFORD, J. Pharmacol, Exp. Therap. 143, 157 (1964).

6. B. WEISS and V.G. LATIES, J. Pharagcol. Exp. Therap. 143, 169 (1964).

7. W.T. BEAVER, S.L. HALLENSTEIN, R.H. HOUDE and-A. ROGERS, Clin. Pharmacol. Therap. I, 741 (1966).

8. W.T. BEAVER, S.L. KALLENSTEIN, R.W. HOUDE and A. ROGERS, Clin. Pheraacol. Therap. 9, 582 (1968).

9. 8.J. WoLE and C.W. GORODENTZKY, J. Pharmacol. Exp. Therap. 154, 632 (1966).

10. R.A. FERRARI, Toxicol. Appl. Pharmacol. 12, 404 (1968).

11. B.A. BERKOHITZ, J.H. ASLIMG, S.M. SHIIDER and E.L. WAY, C11n. Pharmacol. Therep. 10, 320 (1969).

12. A.H. BECKET, J.F. TAYLOR and P. KOUROUMAKIS, J. Pharme Pharmac. 22,123 (1969).

13. K. AHAD and F. MEDZIHRADSKY, Life Sclences, in press.

14. K.A. PITTAN, D. ROSI, R. CHERHUAR, A.J. MEROLA and W.D. CONWAY, Blochem. Pharacel. 18, 1673 (1969). 